@CEDA/TU, 2017, US Library of Congress, Catalog Card No.: 79-915209, ISSN: 2091-0339

The Journal of Development and Administrative Studies (JODAS), Vol. 25(1-2), pp. 47-61

\title{
Invisible Corruption in Iraqi Universities: Causes and Solutions
}

\author{
Muslim Alawi Alsaad ${ }^{1}$ and Abdulridha Nasser Mohsen ${ }^{2}$
}

\begin{abstract}
Corruption is a global phenomenon driving towards the non-productive activities, and its result becomes more risky if corruption is widespread. Corruption in high education institutions has detrimental consequences on the quality of education, the student's ethics, the future opportunities for students, and the quality of future leadership. This paper aims to explore the role of universities in the spread of invisible corruption at the Iraqi high education sector. The main research problem is an attempt to explore the role of students, academic and other staff in the spread of invisible corruption at the Iraqi high education sector, and what best solution are used to limit its effects. This study pursues both deductive and inductive approach and uses the analysis which is supported by both theoretical evidence and statistical techniques. The study was conducted at the University of Basra and the Southern Technical University, where, the sample included professors with experience and specialization in the field of teaching and analyzing corruption in high education. The results showed limited visible corruption in the Iraqi education sector, while Invisible corruption was the most common in the Iraqi high education sector, because of the difficulty of discovering its practices. The spread of this type of corruption was due to the common interests between students and academic and administrative bodies. This requires Popularizing the culture of integrity and exposing corruption and its dangers in the external and internal community levels of Iraq's high education sector.
\end{abstract}

Key words: Corruption, visible Corruption, invisible Corruption, High Education.

\section{Introduction}

There is no debate about the spread of managerial and financial corruption among various societies at the national and regional levels, some researchers and specialists have identified it as a global phenomenon. Some specialized organizations which pursued corruption have explained the serious effects of this phenomenon in figures and data, (Begovic, 2005) stressed that corruption drives towards non-productive activities, and the result becomes riskier if corruption is widespread. Corruption can be described as a social, economic and illegal concept based on five approaches to determine the nature of corruption. They are: the public benefit-based approach, the market-based approach, the job-based approach, the public-opinion based approach, laws and legislation based approach. The unethical behavior results from corruption as a result of a set of criteria that weakens the respect for the existing composition of administrative authority (Khan, 1999). The phenomenon of corruption in Iraq is not different from others in the world, and often appears in the form of bribery, exploitation of public influence, extortion, waste of public money, and the employment of public funds for the others, who are not entitled to them. Other forms of corruption are the evasion and help to evade tax, mediation, leaking of information, employment of people with connections

\footnotetext{
${ }^{1}$ Experienced Professor, Basra, Iraq; email: Moslimaalawi@gmail.com

${ }^{2}$ Teacher, Basra, Iraq; email:abdnaser4@yahoo.com
} 
and closeness in contracts, mood in issuing administrative orders, and obtaining favors for the assignment of contracts or tenders (Tabra, 2014). In its report Saeed (2009) classified Iraq among the four most corrupt countries in the world.

This paper aims to explore the role of universities in the spread of invisible corruption at the Iraqi high education sector, and it suggests some methods to prevent it where corruption has been addressed under the phrase: "What type of corruption has occurred in the Iraqi high education institutions?" Many studies have addressed corruption, and corruption in high education from different aspects, and in different directions, Orkodashvili (2010) pointed out that corruption in high education is difficult to define. What is considered to be a corrupt behavior by some, may be considered acceptable or normal by others. Corruption in high education is a worldwide occurrence in developing countries. It manifests itself through the following activities: favoritism in procurement, favoritism in personnel appointments, manipulation of students' grades, sell-in admissions and grades, private tutoring, and skimming of project grants. Corruption in high education is particularly common in developing countries. It has detrimental consequences on the quality of education, the student's morals, the future opportunities for students, and quality of future leadership (Rumyantseva, 2005). Chinyere \& Chukwuma (2017) aimed to show the dimensions of corruption in Nigerian high institutions, which included students, lecturers, non-academic staff and administrators, the corruption among students included bribing of lecturers for unmerited grades, cultism, and examination malpractice.

Mohamedbhai (2016) oriented toward corruption that can take place at every stage of operation of a HEI, and can involve management, faculty, staff, students, etc.: as setting up of institution, corruption at the level of regulatory agency, political interference in HEI, admission of students: bribery of admission officers, fraud in internal financial management of HEI, Nepotism/favoritism in appointments \& promotion of faculty. This means that students and faculty members of institutions in high education play prominent roles in spreading this corruption. Two types of educational corruption emerge: corruption involving students as agents that have direct effect on their values, beliefs, and life chances (academic corruption), and corruption that does not involve students as agents, but has limited direct effect on them (administrative corruption) (Rumyantseva, 2005). Regardless of the different views on the classification of corruption in high education, corruption in Iraq does not differ much from the common phenomena of corruption in the developing countries. It takes various forms: dysfunctions, cronyism and nepotism, manipulation of the asset values, more complications and procedures, accompanied by loss of time, inaccuracies in the expected results, the manipulation of state support for low income earners or recipients of social care, waste of government resources, and corruption in state enterprises.

However, corruption in Iraqi high education takes other forms such as: bribery, formalist of the lecture performance, exceeding the limits of the job, falsification, interpretation and wrong application of orders and instructions. As a result, the study classifies corruption into two main groups: visible and invisible. The visible corruption means practices that can be discovered through control and financial auditing procedures. While, invisible corruption means practices that is difficult to discover through control and financial auditing. The problem of the study focuses on the detection of the phenomena and causes of invisible corruption in the Iraqi higher education sector. This leads to the main question of the problem: how could the role of universities be explored in the spread of invisible corruption at the Iraqi high education sector? and what are the best methods used to prevent from it?

The problem is identified by the following questions: 
Q1: What is the nature of corruption in Iraqi higher education?

Q2: What are the general characteristics of corruption in Iraqi higher education?

Q3: What are the types of corruption in the Iraqi higher education sector?

Q4: Is the corruption can be more spread at any areas?

Q5: Do you think that the following practices are general of corruption in the Iraqi high education sector?

Q6: What are the detailed causes of corruption among students, staff and teachers?

Q7: Is corruption in higher education different from corruption in other sectors of the state?

To answer these questions, the paper begins by saying: It is necessary to identify the root causes of corruption and the methods of dealing with cases that directly and indirectly have serious effects on the Iraqi high education institutions in the short and long term. The main aim of this paper is to: explore the vital role played by faculty members and students in the spread of corruption in the Iraqi high education sector. The importance of the study is shown by dealing with the phenomena of Invisible corruption, which are difficult to detect by accounting or other means, and the negative reflection of such phenomena on the area of higher education. The analytical approach of this paper is based on the assumption that: faculty members and students play a major role in the spread of invisible corruption in Iraqi high education. This study is different from the previous studies because it reveals the various phenomena of invisible corruption in the institutions of higher education and its negative consequences.

The rest of the paper is structured as follows: the first section deals with literature review, and second deals with the study of frame work and methodology, and the third deals with the views and analysis of the results and discussion, and the fourth deals with the conclusions and study of future prospects.

\section{The Literature Review}

Many studies have addressed corruption, and corruption in high education from different aspects, and in different directions. Myint (2000) identified the causes and consequences of corruption, especially in the context of a least-developed country with considerable regulations and central division, lack of transparency and consistency, as well as institutional weaknesses, such as in the legislative and judicial systems. Moreover, corruption represents the main obstacle to economic development of developing countries. Tanzi \& Davoodi (1998) indicated that (Political corruption destroys the strategic decision-making process of government in investment projects, corruption may increase the amount of money invested against the reduction in total productivity expected of investment. The economists call to limit the increase in investment in the high-corruption countries. Begovic (2005) stressed that corruption is an important constraint in achieving high growth rates because it is contrary to the trends of entrepreneurship and creativity, and the latter is working to allocate resources to productive activities in order to achieve the highest possible return from these activities. While corruption drives toward non-productive activities, the result becomes more risky if corruption is widespread. This means that corruption is the main obstacle to economic development of developing countries, which weaken the development plans. Orkodashvili (2010) pointed out that corruption in high education is difficult to define. What is considered to be corrupt behavior by some, may be considered acceptable or normal by others. Heyneman, Anderson \& Nuraliyeva (2007) mentioned that corruption in education weakens the possibility of increasing educational outputs. Investment in education is substantially reduced when corruption is at higher levels. Mohamedbhai (2016) stated that corruption can take place at every stage of operation in a HEI and can involve management, faculty, staff, 
students, etc. When setting up institutions, corruption at the level of regulatory agency, political interference in HEI, admission of students appears as: bribery of admission officers, fraud in internal financial management of HEI, Nepotism/favoritism in appointment and promotion of faculty.

This means that Corruption is a social, economic, legal and ethical phenomenon practiced by a person or a group through violation of public function or official authority. In order to achieve personal benefits or gains at the expense of overriding the laws and regulations of the public authority (the government) such as (i) it is in high education including students, lecturers, non-academic staff and administrators and also affects and spreads through their actions and (ii) it has serious implications in the long term because it negatively affects the overall performance of the country, and the development plans, and the quality of potential educational levels for the future.

Corruption in Iraqi sectors is characterized by various phenomena that can be observed in the state and society. The corruption may occur in the following cases (i) defects in the performance of the job or overriding the rules and instructions of the job, (ii) manipulation of the assets value, (iii) giving preference to favoritism, (iv) manipulate the money provided by the State to support low income holders, social welfare, (v) Waste in the use of government resources, (vii) a multitude of procedures and complications and the resulting loss of time and inaccuracy in the results and (viii) exploitation of government projects to gain personal benefits.

Khan (1999) assigns that corruption may also occur in the following cases (i) accept cash or donations in order to facilitate access to contracts, (ii) amounts paid for supporting legality of the wrong act, (iii) converting public resources to private sector uses, (iv) intervention in the justice or judicial process, (v) reliance of relatives at recruitment and (vi) the unreal projects and fraud in the collection and estimation of state funds.

The causes of corruption in Iraqi sectors as mentioned in (Www.nazahz.org/search web/trboy) are as follows (i) weak control of the official authority which is responsible for cases of corruption, (ii) weak commitment to implementing laws and regulations relating to combating corruption, (iii) imbalance between the individual's economic construction and its social building, (iv) insufficient income of the employee compared to the function responsible for, and the level of importance and (v) weakness or collapse of the ethical system of society.

It is clear from the above that the causes of corruption revolve around (three) groups as explained in the following:

Group I: International: This includes: (i) illegal practices by foreign investment companies in order to obtain potential gains in the country and (ii) the requirements and benefits of executing development projects against exceptional powers of government officials responsible for this aspect.

Group II: Governmental: This includes the following: (i) weak control of the official authority (the state) responsible for pursuing the cases of corruption, (ii) poor commitment by government officials to the procedures and mechanisms for implementing the laws and legislation that combat corruption, (iii) insufficient laws, legislation and institutional systems to combat corruption, (iv) the multiplicity and continuity of changing laws, regulations, rules, administrative orders and differences in interpretation and (v) weakness or collapse of the ethical system of government and society. 
Group III: Personal: This includes: (i) imbalance between the income of the employee, and the value of the functional responsibility and level of importance, (ii) imbalance between the social and behavioral environment of the person and the economic requirements of the new stage, where it results in a preference for personal benefits more than functional values and (iii) a large area of freedom in action granted to some state employees with regard to the interpretation of laws and the methods of their implementation, and to act accordingly.

Corruption can appear in different situations and different ways, some of them may be visible, others may be invisible, in all cases, they result in direct and indirect costs. These costs may be significant that affect the country's economy, and hinder its development plans, or small cost that affects the person's ability to carry out current or potential tasks. Corruption in high education is defined as the systemic use of public office for private benefit, whose impact is significant on access quality and equity in education (Osipian, 2007). Corruption in the educational institutions is seen as determinant for the quality of education and development (Grekou, 2013). It includes the types of visible and invisible corruption, it affects the efficiency of worker's production in education on the one hand, and affects the long-term output of the educational institutions on the other hand. This is known as the impact of teacher, that summarizes the words "incompetent students today", which will become incompetent teacher's tomorrow. It also says: these situations broadly mean: the output of poor education will affect, in the long term, the quality of economic institutions, educational, and the quality of future generations. It is difficult to control the method of using teaching time, and the level of its scientific and educational benefits, for example. Invisible corruption is often the most important in high education because its long-term consequences result in damage of economic and social structure of the country. Corruption is affected by student, faculty members and society. Therefore, identifying the causes of corruption requires the distinction between these elements and the extent of focusing on any one.

Hence, several questions are raised about this subject including, is corruption caused by students? Is corruption caused by old or new teachers? Is corruption in high education a general phenomenon or special cases? Is corruption has material or scientific aspects? Is corruption accidental or intended phenomenon? Can corruption be identified in institutions of high education and compared to corruption in other institutions in the country?

The above-mentioned notes are summarized in the following:

1. Corruption in high education is characterized in two types (visible and invisible), but invisible corruption is the most important and the most dangerous.It is also common in Iraqi higher education institutions.

2. The importance of invisible corruption in higher education appears in its long-term effects in terms of losses and costs borne by the economy, the society, and the education sector itself.

3. Corruption in high education means the comprehensive and systematic use of the governmental function in order to obtain personal benefit, but its impact will be essential in the quality and justice of the high education at short and long terms.

4. This use may be found in the form of manipulation and fraud in the fields of recruitment, promotion, performance of teachers, processing and distribution of resources, distribution of special benefits, test results, and unseen waste in the inputs and outputs of the educational process.

5. Waste in the educational process also appears in the form of: the imbalance between the number of lecturers and time available for teachers, poor attention to the qualitative level of the educational process, and the low scientific levels of teachers. Concern on success in any ways (legitimate or illegal), focuses on formal aspect rather than scientific in the teaching process, negative social and political influences. 
6. As a result of this wasting is: low scientific levels for students, wasting in the productive time, low in scientific and cognitive values, rise of hidden costs, damage in economic, social and scientific levels in the long-term.

7. Corruption in high education is strengthened by the impact of both community acceptance of the phenomenon of corruption, weakness of the ethical and system values of teachers and employees in the institutions of high education, the economic level of teachers, weak followup and accountability procedures, the dominance of the political side on the scientific side in the educational institution.

From previous studies, it is concluded that (i) the previous studies dealt with corruption in various aspects, but most of them focused on the economic damage resulting from its practice, (ii) corruption in higher education may weaken the outputs of higher education and the possibility of investing in it, (iii) few of previous studies, has dealt with the nature of invisible corruption in higher education, and its impact on the outputs of the university and the ethical system in the university and society, (iv) the present study is an extension of the previous few studies that dealt with the invisible corruption in higher education, and provides more details about the nature of this type of corruption, and its phenomena and the negative consequences that result from it and (v) previous studies form the basis for the formulation of problem questions and study method.

\section{Study Structure and Method}

The study is pursued in the design and remedy methods, the deductive and inductive approaches. The study uses the analysis supported by theoretical evidence in its theoretical part, and uses the analysis supported by statistical techniques in its practical part.This study was conducted at the University of Basra and the Southern Technical University, for the following reasons: proximity to the researchers' work site, the possibility of representing the reality of Iraqi universities in general, the availability of competencies and expertise concerned with the study and diagnosis of corruption in high education. The study followed the method of exploratory research, using two tools to collect the data. The first tool is a checklist to survey the views of intended sample of the university leaders and teacher's specialists in the subject of corruption at the University of Basra, and the Technical university, Basra. The size of sample is 36 cases and 10 of which were not retrieved, 6 have incomplete information, 20 have correct cases with complete information. The second tool is available data from the reports of the Iraqi Integrity Commission, the intended sample included professors with experience and specialization in the field of study and analyzing corruption in high education. Integrity data represent the latest version of Iraqi integrity on time, the field study tries to answer the questions of the problem, which in turn results in the verification of the response to the goals. For data organization and analysis of results, the study has used percentage tables, and qualitative analysis method.

\section{Viewing, analyzing data,and discussing results}

Analyzing the results of the data, collection tools, tables and checklists have been designed to collect opinions of a intended sample of respondents in accordance with the following sequence:

\section{Q1: What is the nature of corruption in Iraqi higher education?}

The answer will be determined by analyzing the data in the following table 1 : 
Table (1) The nature of corruption in the Iraqi high education sector:

\begin{tabular}{|c|c|c|c|c|c|c|c|c|}
\hline S.N. & Question & \multicolumn{3}{|c|}{ General } & \multicolumn{3}{|c|}{ special (Personal) } & comment \\
\hline \multirow[b]{2}{*}{1} & \multirow{2}{*}{$\begin{array}{l}\text { Is the } \\
\text { phenomenon } \\
\text { of corruption } \\
\text { general or } \\
\text { special in the } \\
\text { Iraqi high } \\
\text { education } \\
\text { sector? }\end{array}$} & Total & Actual & Ratio & Total & Actual & Ratio & \multirow[b]{2}{*}{$\begin{array}{l}\text { A mixture of public and } \\
\text { private phenomena, but } \\
\text { the permissibility is for } \\
\text { private corruption } \\
\text { phenomena }\end{array}$} \\
\hline & & 20 & 8 & $40 \%$ & 20 & 12 & $60 \%$ & \\
\hline & Is corruntion & \multicolumn{3}{|l|}{ Yes } & \multicolumn{3}{|l|}{ No } & comment \\
\hline & $\begin{array}{l}\text { education } \\
\text { sector more }\end{array}$ & Total & Actual & ratio & Total & Actual & ratio & \multirow{2}{*}{$\begin{array}{l}\text { The rates of corruption } \\
\text { are almost identical in } \\
\text { all sectors of the Iraqi } \\
\text { state }\end{array}$} \\
\hline 2 & $\begin{array}{l}\text { corruption in } \\
\text { other sectors } \\
\text { of the state? }\end{array}$ & 20 & 3 & $15 \%$ & 20 & 17 & $85 \%$ & \\
\hline
\end{tabular}

It is clear from Table (1) above, which includes the opinions of sample members on the nature of corruption in the Iraqi high education sector, the following is deduced:

- $(60 \%)$ of the respondents said that corruption in the high education sector is a special phenomenon, compared to $40 \%$ of the respondents who emphasize that it is a general phenomenon related to the high education system and its directives.

- $(85 \%)$ of the respondents said that corruption in the Iraqi high education sector is the lowest compared to corruption in the other sectors of the country. About $15 \%$ of the sample's opinions emphasize that the phenomenon of corruption in the Iraqi high education sector, which is more than corruption in other sectors of the country.

- The nature of corruption in Iraqi higher education is public and private,the public is focused on visible corruption, which is almost limited, and the private focus is on the invisible corruption, which is the broader phenomenon. The first question was answered.

Outcome 1: Visible corruption is limited in the high education sector, and its phenomena is centered more on personal behavior than on general systems of the high education.

\section{Q2: What are the general characteristics of corruption in Iraqi higher education?}

Table 2 shows the general characteristics of corruption in the Iraqi high education sector as follows:

- The percentage of poor services provided by the high education sector compared to the other sectors of the state combined is $(33 \%)$. This means that the poor service space provided by the high education sector is equivalent to $33 \%$ of its indication of poor service in the high education sector.

- The proportion of staff who have been bribed in the high education sector compared to other sectors of the state combined is $(12 \%)$ i.e. relatively weak, this shows the weak or limited use of bribery in the high education sector. 
- The proportion of staff who received illegal assistance in recruitment within the high education sector compared to other sectors of the state combined $(62 \%)$, indicating the large number of mediation and personal favors' in this sector.

- The proportion of staff who feel protected in the high education sector compared to other sectors of the state combined, is (147\%), noting the widespread of cases of staff protection by other parties in the event of any wrongdoing or corrupted practices.

Table (2) General characteristics of corruption in the Iraqi high education sector

\begin{tabular}{|l|l|l|l|l|}
\hline No. & Item & $\begin{array}{l}\text { Percentage of } \\
\text { cases of } \\
\text { corruption in } \\
\text { the Iraqi high } \\
\text { education } \\
\text { sector } \\
\text { cases of } \\
\text { corruption in all } \\
\text { other country } \\
\text { institutions }\end{array}$ & $\begin{array}{l}\text { Percentage of } \\
\text { cases of } \\
\text { corruption in the } \\
\text { Iraqi high } \\
\text { education sector } \\
\text { to the percentage } \\
\text { of cases of } \\
\text { corruption in all } \\
\text { other country } \\
\text { institutions }\end{array}$ \\
\hline 1 & $\begin{array}{l}\text { Poor services in the high } \\
\text { education sector }\end{array}$ & $30 \%$ & $33 \%$ \\
\hline 2 & $\begin{array}{l}\text { Percentage of Staff who } \\
\text { have been bribed }\end{array}$ & $1.8 \%$ & $15 \%$ & $12 \%$ \\
\hline 3 & $\begin{array}{l}\text { Staff who practice illegal } \\
\text { methods to recruitment } \\
\text { others }\end{array}$ & $16 \%$ & $26 \%$ & $62 \%$ \\
\hline 4 & $\begin{array}{l}\text { Staff who get protection } \\
\text { From the high authorities }\end{array}$ & $50 \%$ & $34 \%$ & $147 \%$ \\
\hline
\end{tabular}

Source: Annual Report (2011)

The characteristics of corruption in Iraqi higher education are summarized as follows: the greatest proportion of corruption appeared in staff receiving protection from others. The remaining characteristics of corruption i.e., poor service, bribery and especially recruitment were the lowest. The second question was answered.

Outcome 2: There is a limited visible corruption in the Iraqi high education. But it is more widespread in phenomenon of mediation, and the effect of personal relationships.

Outcome 3: The lack of clarity of invisible corruption practices within the Iraqi high education sector is the reason behind the difficulty of diagnosing it, although it is the characteristic that illustrates corruption in this sector.

\section{Q3: What are the types of corruption in the Iraqi higher education sector?}

Table 3 shows some cases of corruption in the Iraqi high education sector:

- The percentage of cases of visible corruption (such as bribery, embezzlement, forgery) reached $36 \%$ of the total number of cases of corruption in the Iraqi high education sector.

- The percentage of cases of invisible corruption, which is difficult to determine, due to physical or other consequences reached (64\%) of the total cases of corruption in the Iraqi high education sector. 
- This means that the cases of corruption that are invisible (or whose results are not immediately discovered) in the Iraqi high education sector are the most common compared with the cases of visible corruption. This points to the answer of the (Q3).

Table (3) Some types of corruption in the Iraqi high education:

\begin{tabular}{|l|l|l|l|l|}
\hline Seq. & Case & number & ratio & Comment \\
\hline 1 & Bribery & 15 & $11 \%$ & $\begin{array}{l}\text { Its practice is limited compared with } \\
\text { other practices of corruption }\end{array}$ \\
\hline 2 & $\begin{array}{l}\text { The override on the } \\
\text { powers of the function }\end{array}$ & 25 & $19 \%$ & $\begin{array}{l}\text { Its practice is limited compared with } \\
\text { other practices of corruption }\end{array}$ \\
\hline 3 & Embezzlement & 20 & $15 \%$ & $\begin{array}{l}\text { Its practice is limited compared with } \\
\text { other practices of corruption }\end{array}$ \\
\hline 4 & Counterfeiting & 13 & $10 \%$ & $\begin{array}{l}\text { Its practice is limited compared with } \\
\text { other practices of corruption }\end{array}$ \\
\hline 5 & Others & 60 & $45 \%$ & $\begin{array}{l}\text { Its practice is large compared with } \\
\text { other practices of corruption }\end{array}$ \\
\hline 6 & Total & 133 & $100 \%$ & $\begin{array}{l}\text { The results indicate a widespread } \\
\text { phenomenon of invisible corruption }\end{array}$ \\
\hline
\end{tabular}

Source: Annual Report (2005)

Outcome 4: Invisible corruption is the most common in the Iraqi high education institutions.

\section{Q4: Is the corruption can be more spread at any areas?}

The answers were organized and summarized according to the analysis process as in Table 4:

Table (4) Areas of higher education where corruption is appeared

\begin{tabular}{|c|c|c|c|c|c|c|c|c|c|c|c|c|}
\hline Item & \multicolumn{3}{|c|}{ student } & \multicolumn{3}{|c|}{ staff } & \multicolumn{4}{|c|}{ Teacher } & \multicolumn{2}{|c|}{ Total } \\
\hline \multirow{2}{*}{$\begin{array}{l}\text { From } \\
\text { your } \\
\text { opinion, } \\
\text { which } \\
\text { areas are } \\
\text { the } \\
\text { corruptio } \\
\text { n can be } \\
\text { more } \\
\text { spread? }\end{array}$} & $\begin{array}{l}\text { sampl } \\
\text { e }\end{array}$ & $\begin{array}{l}\text { Actua } \\
1\end{array}$ & ratio & $\begin{array}{l}\text { sampl } \\
\mathrm{e}\end{array}$ & $\begin{array}{l}\text { Actua } \\
1\end{array}$ & ratio & $\begin{array}{l}\text { sampl } \\
\mathrm{e}\end{array}$ & $\begin{array}{l}\text { Actua } \\
1\end{array}$ & ratic & $\begin{array}{l}\text { sampl } \\
\text { e }\end{array}$ & $\begin{array}{l}\text { Actua } \\
1\end{array}$ & ratio \\
\hline & 20 & 4 & $\begin{array}{l}20 \\
\%\end{array}$ & 20 & 4 & $\begin{array}{l}20 \\
\%\end{array}$ & 20 & 2 & $\begin{array}{l}10 \\
\%\end{array}$ & 20 & 10 & $\begin{array}{l}50 \\
\%\end{array}$ \\
\hline
\end{tabular}

Table (4) shows the rates of corruption in the institutions of high education as $(50 \%)$ of the opinions of the sample indicated that corruption exists in the three levels: student, staff, and teachers. The least corrupt level is the teachers level, and that the largest proportion of corruption occurs within the student and administrative bodies.

Outcome 5: Invisible corruption is practiced in higher education, in almost equal proportions in the fields of student, staff, and teachers. 
Q5: Do you think that the following practices are general of corruption in the Iraqi high education sector?

Table (5) Summary of the responses of the sample members on the general causes of Corruption

\begin{tabular}{|c|c|c|c|c|c|}
\hline Seq. & Item & $\begin{array}{l}\text { Sample } \\
\text { size }\end{array}$ & $\begin{array}{l}\text { Actual } \\
\text { responds }\end{array}$ & Ratio & $\begin{array}{l}\text { importance } \\
\text { sequence }\end{array}$ \\
\hline 1 & $\begin{array}{l}\text { Low scientific level for } \\
\text { teachers }\end{array}$ & 20 & 16 & $80 \%$ & First \\
\hline 2 & $\begin{array}{l}\text { Low scientific level of } \\
\text { students }\end{array}$ & 20 & 15 & $75 \%$ & Third \\
\hline 3 & $\begin{array}{l}\text { Student preference culture of } \\
\text { success instead culture of } \\
\text { learning }\end{array}$ & 20 & 15 & $75 \%$ & Third \\
\hline 4 & $\begin{array}{l}\text { Economic conditions and } \\
\text { limited income of the } \\
\text { university employee }\end{array}$ & 20 & 10 & $50 \%$ & Fifth \\
\hline 5 & $\begin{array}{l}\text { Spreading the culture of } \\
\text { corruption over the } \\
\text { community level }\end{array}$ & 20 & 14 & $70 \%$ & Fourth \\
\hline 6 & $\begin{array}{l}\text { Failing in detecting and } \\
\text { combating corruption }\end{array}$ & 20 & 17 & $85 \%$ & First \\
\hline
\end{tabular}

It is clear from Table (5): that the causes of corruption (general) in the institutions of the Iraqi high education sector include the following:

The results of ranking the corruption causes, according to their importance, indicate that the most influential reasons for the emergence of corruption among Iraqi high education institutions (universities), according to this study are: The weakness of pursuing the procedures of detecting and dealing with corruption as well as the low level of scientific detection. While the weakest and least influential causes are economic conditions and limited employee income which leads to the answer for the (Q5)

\section{Q6: What is detailed causes of corruption among students, staff and teachers?}

It is clear from table (6): that the causes of corruption (in detail) in the institutions of the Iraqi high education sector include the following:

The detailed causes of corruption among students, staff, and teachers explained this fact, by limited training and educational programs that improve the performance of teaching and employees, as well as the effects of culture and social values. These are characterized by concern on personal interests and benefits, that depend on illegal support for violations and abuses in the profession of education which lead to the answer for the (Q6). 
Table (6) Detailed causes of corruption among students, staff and teachers:

\begin{tabular}{|c|c|c|c|}
\hline item & Student & staff & teacher \\
\hline \multirow{5}{*}{$\begin{array}{l}\text { What is from your } \\
\text { opinion the reasons } \\
\text { that justify the } \\
\text { emergence of } \\
\text { corruption at any of } \\
\text { the following } \\
\text { levels: (students, } \\
\text { teachers, and staff) }\end{array}$} & $\begin{array}{l}1-\text { Dropout and } \\
\text { weak discipline }\end{array}$ & $\begin{array}{l}\text { 1-The imbalance } \\
\text { between employee's } \\
\text { income and the value } \\
\text { of functional } \\
\text { responsibility assigned } \\
\text { to him }\end{array}$ & $\begin{array}{l}\text { 1- Entry of bad values } \\
\text { and habits to the } \\
\text { campus }\end{array}$ \\
\hline & $\begin{array}{l}2 \text { - Low scientific } \\
\text { performance }\end{array}$ & $\begin{array}{l}\text { 2- Limited employee } \\
\text { ability to bear his / her } \\
\text { functional } \\
\text { responsibility, } \\
\text { including commitment } \\
\text { to official working } \\
\text { hours }\end{array}$ & $\begin{array}{l}2 \text { - Dominance of } \\
\text { material values and } \\
\text { close personal gains } \\
\text { over scientific values } \\
\text { and professional } \\
\text { ethics }\end{array}$ \\
\hline & $\begin{array}{l}3 \text { - Lack of student } \\
\text { interest in the } \\
\text { curricula, } \\
\text { regulations and } \\
\text { instructions } \\
\text { because they feel } \\
\text { no availability of } \\
\text { protection and } \\
\text { support for them }\end{array}$ & $\begin{array}{l}3 \text { - Lack of training and } \\
\text { educational programs } \\
\text { that enhance functional } \\
\text { efficiency }\end{array}$ & $\begin{array}{l}\text { 3- Weak management } \\
\text { ability in controlling } \\
\text { order }\end{array}$ \\
\hline & $\begin{array}{l}4 \text { - Students are } \\
\text { trying to take an } \\
\text { easier route to } \\
\text { success }\end{array}$ & & $\begin{array}{l}4-\text { Limited } \\
\text { requirement of } \\
\text { preparing teachers, } \\
\text { and lack of effective } \\
\text { training and } \\
\text { educational programs }\end{array}$ \\
\hline & $\begin{array}{l}\text { 5- Repeating } \\
\text { examinations for } \\
\text { students who fail, } \\
\text { and transit them } \\
\text { from one stage to } \\
\text { another, as well as } \\
\text { the multiplicity and } \\
\text { differences in } \\
\text { administrative } \\
\text { instructions and } \\
\text { examinations }\end{array}$ & & $\begin{array}{l}5 \text { - Weak and } \\
\text { ineffective control } \\
\text { systems }\end{array}$ \\
\hline
\end{tabular}

Outcome 6: The environment surrounding the educational institutions is the most influential for the emergence of corruption, compared with the effects of the internal media.

\section{Q7: Is corruption in higher education different from corruption in other sectors of the state?}

Table (7) summarizes the characteristics of corruption practices in the institutions of the Iraqi high education sector, which include the following: 
- All the characteristics of corruption practices in the table above describe the corruption phenomena and their nature in this sector.

- Characteristics of the corruption phenomena describe the invisible corruption because their practices do not involve direct benefits or negative outcomes that can be easily detected. For example, the formal performance of a job, time available, and stealing research from the Internet, are all difficult to detect or identify in the short term.

- The most common corruption practices in these institutions fall in the nature of performing the job by the employee or teacher, and in achieving personal benefits from that. However, the form of this performance that cannot be easily detected or identified which points out the answer of the (Q7).

Table (7) Summary of the characteristics of corruption practices in the institutions of the Iraqi high education sector:

\begin{tabular}{|c|c|c|c|c|c|}
\hline & Item & $\begin{array}{l}\text { Sample } \\
\text { size }\end{array}$ & $\begin{array}{l}\text { Actual } \\
\text { responds }\end{array}$ & ratio & $\begin{array}{l}\text { Importance } \\
\text { rank }\end{array}$ \\
\hline 1 & $\begin{array}{l}\text { Reduction in the value of intended job } \\
\text { performance outputs }\end{array}$ & 20 & 17 & $85 \%$ & First \\
\hline 2 & $\begin{array}{l}\text { Clear waste of expected job performance } \\
\text { outputs }\end{array}$ & 20 & 16 & $80 \%$ & Second \\
\hline 3 & $\begin{array}{l}\text { Deficiency in the employee performance of } \\
\text { the tasks assigned to him }\end{array}$ & 20 & 15 & $75 \%$ & Third \\
\hline 4 & $\begin{array}{l}\text { Lack of utilization of time available for } \\
\text { work }\end{array}$ & 20 & 15 & $75 \%$ & Third 1 \\
\hline 5 & $\begin{array}{l}\text { Low scientific levels of students and } \\
\text { graduates }\end{array}$ & 20 & 17 & $85 \%$ & First 1 \\
\hline 6 & Cheating & 20 & 15 & $75 \%$ & Third 2 \\
\hline 7 & $\begin{array}{l}\text { Some students and teachers steal research } \\
\text { from the internet }\end{array}$ & 20 & 16 & $80 \%$ & Second 1 \\
\hline 8 & Fraud in grades and test records & 20 & 12 & $60 \%$ & Fifth \\
\hline 9 & $\begin{array}{l}\text { Close and non-objective relationship } \\
\text { between students and teachers }\end{array}$ & 20 & 13 & $65 \%$ & Forth \\
\hline
\end{tabular}

Outcome 7: Practices of corruption in the Iraqi high education differ from practices in other sectors of the state, because they are characterized by the phenomenon of invisible corruption.

\section{Q8: What are the sample member views about the expected results of corruption practice in the Iraqi higher education institution?}

Table (8) shows a summary of the views of the sample members on the expected results of corruption practices in the Iraqi high education sector, as follows:

The ratio of opinions of the sample members ranged from(70\% - 90\%). That means the corruption practices in Iraqi high education institutions appear as: low level of graduate performances when practicing their actual jobs, the low scientific and ethical levels of future generations, the decline in ethical and failure of behavioral values in society and to implement the requirements of development plans. 
Table (8) Summary of sample member views on the expected results of corruption practice in the Iraqi high education institutions:

Do you think that the subsequent results are the result of the corruption practices in
Iraqi high education institutions?

\begin{tabular}{|l|l|l|l|l|c|}
\hline Seq. & \multicolumn{1}{|c|}{ Item } & $\begin{array}{l}\text { Sample } \\
\text { size }\end{array}$ & $\begin{array}{l}\text { Actual } \\
\text { responds }\end{array}$ & Ratio & $\begin{array}{l}\text { importance } \\
\text { sequence }\end{array}$ \\
\hline 1 & Increase of visible and invisible costs & 20 & 16 & $80 \%$ & Third \\
\hline 2 & $\begin{array}{l}\text { Low level graduate performance } \\
\text { when they practice their actual jobs }\end{array}$ & 20 & 17 & $85 \%$ & Second \\
\hline 3 & $\begin{array}{l}\text { Low scientific and ethical level for } \\
\text { future generations }\end{array}$ & 20 & 18 & $90 \%$ & First \\
\hline 4 & $\begin{array}{l}\text { Failure to respond to implement } \\
\text { requirements of development plans }\end{array}$ & 20 & 14 & $70 \%$ & Fourth \\
\hline 5 & $\begin{array}{l}\text { Decline in ethical and behavioral } \\
\text { values of society }\end{array}$ & 20 & 17 & $85 \%$ & Second 1 \\
\hline
\end{tabular}

Outcome 8: The practice of corruption in the institutions of the Iraqi high education sector is invisible and leaves harmful effects in the long term. In addition, its impact is reflected on development and community building including ethical and behavioral values of society, scientific level of colleges and universities and development plans.

The result of this analysis indicated the truth of the (Q8). The corruptions in the Iraqi high education institutions have harmful and dangerous consequences in the short and long-term plans.

\section{Conclusion and Recommendation}

The results from the previous presentation showed a limited visible corruption in the Iraqi education sector, despite the spreading of mediation phenomena, and the effects of personal relationships. The practice of this type of corruption is a result of personal behavior more than the negative effects resulting from faults in the system of high education, and its ability to provide evidence on the practice of this type of corruption. In particular, the general behavior of the Iraqi society may foster many of these practices, as a result of the weakness of the system values in society. Invisible corruption is the most common in the Iraqi high education sector, because of the difficulty of discovering its practices. Because they appear as a legitimate and responsive to the instructions and regulations in force, but in essence it is empty of scientific and behavioral content because they are characterized by lost time, unproductive labor, and involution on rules and regulations. Moreover, they focus on the quantity of outputs more than their quality, in order to achieve personal benefits, which appear to be subject to administrative and legal rules. The best example is the reduction in the value of the intended outputs of the job. The spread of this type of corruption is encouraged by the negative effects of the internal and external environment of high education sector. The reason for its spread in the sector of students and academic and administrative bodies, is due to the common interests between students and these bodies. The conclusions can be summarized as (i) most of the phenomena of corruption in Iraqi higher education are characterized by "invisible corruption", (ii) it is widely appearing in people receiving support from higher education authorities, (iii) this corruption is practiced in higher education, in the fields of student, staff, and teachers, (iv) the corruption in the Iraqi high education differs from practices in other sectors of the state, because they are characterized by the phenomenon of invisible corruption, (v) the corruption in the institutions of the Iraqi high 
education sector is invisible and leaves harmful effects in the long term and (vi) political and cultural factors are the most important determinants of implementation. Based on the study following recommendations can be made:

Recommendation 1: We should Popularize the culture of integrity and expose corruption and its dangers in the external and internal community levels of Iraq's high education sector through (i) allocating the media programs through all its channels (audio and visual) to disseminate cases of corruption in the Iraqi high education system and expose the risks resulting from them and through all possible means of disposal, (ii) allocation of intensive programs to detect the corruption phenomena in the Iraqi high education sector, depending on available and influential channels such as hours of supervision, lectures of democracy, other lectures, and programmed meetings with students, teachers and staff (iii) Emphasizing on the role of religion and its practices in the fight against various phenomena of corruption, through lectures by clerics and preachers of mosques.

Recommendation 2: The possible remedies for corruption according to the level of authority and responsibility of the official can be brought through (i) establishing clear instructions and proper procedures for governing the staff exploitation productive time of their jobs, (ii) monitoring the abnormal approaches, however small and work to address them first and(iii) developing accurate evaluation and control criteria to evaluate the work of staff and academic commissions and use feedback information for the correction procedures.

Recommendation 3: Clarity and transparency of the procedures can be carried out by government and other agencies responsible for detecting and combating corruption through (i) issuing clear orders and instructions obliging the official in any location to work on detecting and combating corruption and considering it as part of his official duties, (ii) issuing formal procedure to eliminate the phenomenon of invisible corruption and (iii) establishing strict controls to prevent the staff from favoritism or oriented towards the sources of corruption, and supporting these controls by the values of transparency, accountability and justice.

Recommendation 4: We should develop rules and procedures to prevent the introduction of corrupt social values and practices into the university community through (i) establishing strict rules and regulations to hold accountable those who adopt corrupt social values and practices within the university community such as tribalism, protection of corrupt people, mediation and nepotism, (ii) developing ethical regulation or code of ethics to regulate the social behavior of the university and support them with legitimacy and legal force when implemented and (iii) considering the commitment to values and ethical practices of university as part of assessing the university staff.

\section{References}

Annual Report (2011). Corruption and the Challenges of Integrity in the Iraqi. Annual Report, pp. 15, 38, 49

Annual Report. (2005). Annual Report. Public Integrity Commission, Iraq.

Begovic, B. (2005). Corruption: concepts, types, causes and consequences. Center for Liberal-Democratic Studies, Year III No, 26.

Chinyere, A.P. \& Chukwuma, O. (2017). Corruption and Administration of Higher Education Institutions in Nigeria. World Journal of Social Science, 4(2), 12-17.

Grekou, D. E. (2013). Essays in Macroeconomics of Development. Electronic Thesis and Dissertation Repository. 1209. https://ir.lib.uwo.ca/etd/1209

Heyneman, S. P., Anderson, K. H., \& Nuraliyeva, N. (2007). The cost of corruption in higher education. Comparative Education Review, 52(1), 1-25. 
Khan, M. M. (1999). Political and administrative corruption: concepts, comparative experiences and Bangladesh case. A Paper Prepared for Transparency International: Bangladesh Chapter, Dhaka.

Mohamedbhai, G. (2016). The scourge of fraud and corruption in higher education. International Higher Education, (84), 12-14.

Myint, U. (2000). Corruption: Causes, consequences and cures. Asia pacific development journal, 7(2), 33-58.

Orkodashvili, M. (2010). Corruption in Higher Education: Causes, Consequences, Reforms: The Case of Georgia. Consequences, Reforms (August 10, 2010).

Osipian, A. L. (2007). Corruption in higher education: Conceptual approaches and measurement techniques. Research in Comparative and International Education, 2(4), 313-332.

Rumyantseva, N. L. (2005). Taxonomy of corruption in higher education. Peabody Journal of Education, 80(1), 81-92.

Saeed, K.A. (2009). Transparency International Corruption Perceptions Index 2007. Administration and Management Review, 20(1),52-58.

Tabra, H. \& Faris, A. (2014). Assess the size of the phenomenon of corruption in Iraqi governmental institutions: from the point of view of universities teachers. Journal of Integrity and Transparency for Research and Studies, 7, 1-10.

Tanzi, V., \& Davoodi, H. (1998). Corruption, public investment, and growth. In The welfare state, public investment, and growth (pp. 41-60). Springer, Tokyo. 